\title{
Bacterial diversity in the alimentary canal of earthworms
}

\begin{abstract}
The soil bears infinite life that promotes diverse microflora. Soil bacteria viz., Bacillus, Pseudomonas and Streptomyces etc., are prolific producers of secondary metabolites which act against numerous co-existing phytopathogeic fungi and human pathogenic bacteria. Microbial communities also support a large number of soil invertebrates, which in turn have an important regulatory effect on the microbial populations. Decomposition of organic material is assumed to be mainly mediated by microorganisms. The rate and extent of the decomposition depends on the chemical composition of the material, environmental factors, and on the microbial community. The activity of the decomposing microorganisms is accelerated by the activity of the soil fauna. The microorganisms show a high degree of specialization and display a large number of enzymes for the breakdown of organic matter. It is certainly proven that the growth of earthworms is dependent on microbial associations. In fact, microorganisms are largely responsible for the decomposition of the materials ingested by earthworms and in turn earthworm regulates modifications in microbial communities thus sharing a mutualistic relationship.
\end{abstract}

Keywords:gut of earthworm, gut transit time, gut associated microbes, gut symbiosis, vermicasts
Volume 6 Issue 3 - 2018

Vitthalrao B Khyade
Sericulture Unit, Agricultural Development Trust Baramati, India

Correspondence: Vitthalrao B Khyade, APIS, Shrikrupa Residence, Teachers Society, Malegaon Colony (Baramati), Maharashtra, India, Email vbkhyade.2016@gmail.com

Received: January 13, 2018| Published: May 16, 2018

\section{Introduction}

Earthworm's ability to increase plant nutrient availability is likely to be dependent on the activity of earthworm gut microflora. Earthworms indirectly influence the dynamics of soil chemical processes, by comminuting the litter and affecting the activity of the soil microflora. ${ }^{1-3}$ Interactions between earthworms and microorganisms seem to be complex. Earthworms ingest plant growth-promoting rhizospheric bacteria such as Pseudomonas, Rhizobium, Bacillus, Azosprillium, Azotobacter, etc. along with rhizospheric soil, and they might get activated or increased due to the ideal micro-environment of the gut. Therefore earthworm activity increases the population of plant growthpromoting rhizobacteria (PGPR). ${ }^{4}$ This specific group of bacteria stimulates plant growth directly by solubilization of nutrients, ${ }^{5,6}$ production of growth hormone, 1-aminocyclopropane-1-carboxylate (ACC) deaminase, ${ }^{7}$ nitrogen fixation, ${ }^{8}$ and indirectly by suppressing fungal pathogens. Antibiotics, fluorescent pigments, siderophores and fungal cell-wall degrading enzymes namely chitinases and glucanases 6,8-12 produced by bacteria mediate the fungal growth-suppression. Earthworms are reported to have association with such free living soil bacteria and constitute the drilosphere. ${ }^{13}$ Earthworm microbes mineralize the organic matter and also facilitate the chelation of metal ions. ${ }^{14,15}$ Gut of earthworms L. terrestris, Allolobophora caliginosa and Allolobophora terrestris were reported to contain higher number of aerobes compared to soil. ${ }^{16}$ Earthworms increased the number of microorganisms in soil as much as five times ${ }^{17}$ and the number of bacteria and 'actinomycetes' contained in the ingested material increased upto 1,000 fold while passing through their gut. ${ }^{18}$ Similar increase was observed in plate counts of total bacteria, proteolytic bacteria and actinomycetes by passage through earthworms gut. ${ }^{16,19-}$ ${ }^{21}$ Similarly microbial biomass either decreased, ${ }^{3,21}$ or increased ${ }^{22}$ or remained unchanged ${ }^{19}$ after passage through the earthworm gut. An oxalate-degrading bacterium Pseudomonas oxalaticus was isolated from intestine of Pheretima species ${ }^{23}$ and an actinomycete Streptomyces lipmanii was identified in the gut of Eisenia lucens..${ }^{24}$ Scanning electron micrographs provided evidence for endogenous microflora in guts of earthworms, L. terrestris and Octolasion cyaneum. ${ }^{25}$ Gut of E. foetida contained various anaerobic N2-fixing bacteria such as Clostridium butyricum, $C$. beijerinckii and $C$. paraputrificum. ${ }^{26}$ Alimentary canal of Lumbricus rubellus and Octolasium lacteum were found to contain more numbers of aerobes and anerobes ${ }^{27}$ and culturable denitrifiers. Earthworms harbor 'nitrogen-fixing' and 'decomposer microbes' in their gut and excrete them along with nutrients in their excreta. ${ }^{28}$ Earthworms stimulate and accelerate microbial activities by increasing the population of soil microorganisms, ${ }^{29}$ microbial numbers and biomass, ${ }^{3}$ by improving aeration through burrowing actions. Vermicomposting modified the original microbial community of the waste in a diverse way. Actinobacteria and Gamma proteobacteria were abundant in vermicompost, while conventional compost contained more Alpha proteobacteria and Bacteriodetes, the bacterial phylogenetic groups typical of non-cured compost. ${ }^{30}$ Total bacterial counts exceeded 10-10/g of vermicompost and it included nitrobacter, azotobacter, rhizobium, phosphate solubilizers and actinomycetes. ${ }^{31}$ Molecular and culture-dependent analyses of bacterial community of vermicompost showed the presence of $\alpha$-Proteobacteria, $\beta$-Proteobacteria, $\gamma$-Proteobacteria, Actinobacteria, Planctomycetes, Firmicutes and Bacteroidetes. Several findings showed considerable increase in total viable counts of actinomycetes and bacteria in the worm treated compost. ${ }^{32,33}$ The increase of microbial population may be due to the congenial condition for the growth of microbes within the digestive tract of earthworm and by the ingestion of nutrient rich organic wastes which provide energy and also act as a substrate for the growth of microorganisms. ${ }^{34}$ The differences in microbial species, numbers and activity between the earthworm alimentary canal or burrow and bulk soil indirectly support the hypothesis that the bacterial community structures of these habitats are different from those of the soil. Specific phylogenetic groups of bacteria such as Aeromonas hydrophila in E. foetida ${ }^{35}$ fluorescent pseudomonads in 
L. terrestris, ${ }^{36}$ and Actinobacteria in L. rubellus ${ }^{37}$ have been found in higher numbers in earthworm guts, casts, or burrows.

Enzymatic activity characterization and quantification has a direct correlation with type and population of microbes and reflects the dynamics of the composting process in terms of the decomposition of organic matter and nitrogen transformations and provide information about the maturity of the compost. ${ }^{38}$ Wormcasts contain higher activities of cellulase, amylase, invertase, protease, peroxidase, urease, phosphatase and dehydrogenase., ${ }^{3,39}$ Dehydrogenase is an intracellular enzyme related to the oxidative phosphorylation process ${ }^{40}$ and is an indicator of microbial activity in soil and other biological ecosystems. ${ }^{41}$ The maximum enzyme activities (cellulase, amylase, invertase, protease and urease) were observed during 21-35 days in vermicomposting and on 42-49 days in conventional composting. Also, microbial numbers and their extracellular enzyme profiles were more abundant in vermicompost produced from fruitpulp, vegetable waste, groundnut husk and cowdung compared to the normal compost of the same parental origin..$^{33}$ Pseudomonas, Paenibacillus, Azoarcus, Burkholderia, Spiroplasm, Acaligenes, and Acidobacterium, the potential degraders of several categories of organics are seen associated with the earthworm's intestine and vermicasts. ${ }^{28}$ Firmicutes viz., Bacillus benzoevorans, B. cereus, B. licheniformis, B. megaterium, B. pumilus, B. subtilis, B. macroides; Actinobacteria namely Cellulosimicrobium cellulans, Microbacterium spp., $M$. oxydans; Proteobacteria such as Pseudomonas spp., P. libaniensis; ungrouped genotypes Sphingomonas sp., Kocuria palustris and yeasts namely Geotrichum spp. and Williopsis californica were reported from vermicomposts. ${ }^{42}$ Pinel et al. ${ }^{43}$ reported the presence of a novel nephridial symbiont, Verminephrobacter eiseniae from $E$. foetida. Ochrobactrum sp., Massilia sp., Leifsonia sp. and bacteria belonging to families Aeromonadaceae, Comamonadaceae, Enterobacteriaceae, Flavobacteriaceae, Moraxellaceae, Pseudomonadaceae, Sphingobacteriaceae, Actinobacteria and Microbacteriaceae were reported to occur in earthworms alimentary canal. The microbial flora of earthworm gut and cast are potentially active and can digest a wide range of organic materials and polysaccharides including cellulose, sugars, chitin, lignin, starch and polylactic acids..$^{30,44,45}$ Single-strand conformation polymorphism (SSCP) profiles on the diversity of eight bacterial groups viz., Alphaproteobacteria, Betaproteobacteria, Bacteroidetes, Gammaproteobacteria, Deltaproteobacteria, Verrucomicrobia, Planctomycetes, and Firmicutes from fresh soil, gut, and casts of the earthworms L. terrestris and Aporrectodea caliginosa showed the presence of Bacteroidetes, Alphaproteobacteria, Betaproteobacteria and representatives of classes Flavobacteria, Sphingobacteria (Bacteroidetes) and Pseudomonas spp. in the worm casts in addition to unclassified Sphingomonadaceae (Alphaproteobacteria) and Alcaligenes spp. (Betaproteobacteria). ${ }^{46-49}$

Conclusively enough, the activity of the decomposing microorganisms is accelerated by the activity of the soil fauna. The microorganisms show a high degree of specialization and display a large number of enzymes for the breakdown of organic matter. It is certainly proven that the growth of earthworms is dependent on microbial associations. In fact, microorganisms are largely responsible for the decomposition of the materials ingested by earthworms and in turn earthworm regulates modifications in microbial communities thus sharing a mutualistic relationship.

\section{Acknowledgements}

None.

\section{Conflict of interest}

Authors declare there is no conflict of interest.

\section{References}

1. Petersen H, Luxton MA. A comparative analysis of soil fauna populations and their role in decomposition process. Oikos. 1982;39(3):287-388.

2. Lee KE. Earthworms: Their ecology and relationships with soils and land use. Sydney: Academic Press; 1985.

3. Edwards CA, Bohlen PJ. Biology and Ecology of earthworms. London: Chapman and Hall; 1996. p. 426.

4. Sinha RK, Agarwal S, Chauhan K, et al. The wonders of earthworms and its vermicompost in farm production: Charles Darwin's 'friends of farmers', with potential to replace destructive chemical fertilizers from agriculture. Agricultural sciences. 2010;1(2):76-94.

5. Ayyadurai N, Ravindra Naik P, Sakthivel N. Functional characterization of antagonistic fluorescent pseudomonads associated with rhizospheric soil of rice (Oryza sativa L.). J Microbiol Biotechnol. 2007;17(6):919-927.

6. Ravindra NP, Raman G, Badri Narayanan K, et al. Assessment of genetic and functional diversity of phosphate solubilizing fluorescent pseudomonads isolated from rhizospheric soil. BMC Microbiol. 2008;8:230.

7. Correa JD, Barrios ML, Galdona RP. Screening for plant growth promoting rhizobacteria in Chamaecytisus proliferus (tagasaste), a forage tree-shrub legume endemic to the Canary Islands. Plant Soil. 2004;266(1-2):75-84.

8. Han J, Sun L, Dong X, et al. Characterization of a novel plant growth-promoting bacteria strain Delftia tsuruhatensis HR4 both as a diazotroph and a potential biocontrol agent against various pathogens. Syst Appl Microbiol. 2005;28(1):66-76.

9. Sunish KR, Ayyadurai N, Pandiaraja P, et al. Characterization of antifungal metabolite produced by a new strain Pseudomonas aeruginosa $\mathrm{PuPa} 3$ that exhibits broad-spectrum antifungal activity and biofertility traits. $J$ Appl Microbiol. 2005;98(1):145-154.

10. Jha BK, Gandhi Pragash M, Cletus J, et al. Simultaneous phosphate solubilization potential and antifungal activity of new fluorescent pseudomonad strains, Pseudomonas aeruginosa, P. plecoglossicida and P. mosselii. $W J$ Microbiol Biotech. 2009;25(4):573-581.

11. Pathma J, Ayyadurai N, Sakthivel N. Assessment of genetic and functional relationship of antagonistic fluorescent pseudomonads of rice rhizosphere by repetitive sequence, protein coding sequence and functional gene analyses. J Microbiol. 2010;4(6)8:715-727.

12. Pathma J, Kamaraj Kennedy R, Sakthivel N. Mechanisms of fluorescent pseudomonads that mediate biological control of phytopathogens and plant growth promotion of crop plants. In: Maheswari DK, editor. Bacteria in Agrobiology: Plant Growth Responses. Berlin: Springer Verlag; 2011a. p. 77-105.

13. Ismail SA. Earthworms in soil fertility management. In: Thampan PK, editor. Organic Agriculture. 1995; 77-100.

14. Pizl V, Novokova A. Interactions between microfungi and Eisenia andrei (Oligochaeta) during cattle manure vermicomposting. Pedobiologia. 1993;47(5-6):895-899.

15. Canellas LP, Olivares FL, Okorokova FAR. Humic acids isolated from earthworm compost enhance root elongation, lateral root emergence and plasma membrane $\mathrm{H}+-$ ATPase activity in maize roots. Plant Physiol. 2002;130(4):1951-1957.

16. Parle JN. A Microbiological Study of Earthworm Casts. J Gen Microbiol. $1963 ; 31: 13-22$.

17. Edwards CA, Lofty R. The Biology of Earthworms. London: Chapmann and Hall; 1977. 
18. Edwards CA, Fletcher KE. Interaction between earthworms and microorganisms in organic matter breakdown. Agric Ecosyst Environ. 1988;20:235-249.

19. Daniel O, Anderson JM. Microbial biomass and activity in contrasting soil material after passage through the gut of earthworm Lumbricus rubellus Hoffmeister. Soil Biol Biochem. 1992;24:465-470.

20. Pedersen JC, Hendriksen NB. Effect of passage through the intestinal tract of detritivore earthworms (Lumbricus spp.) on the number of selected gram-negative and total bacteria. Biol Fertil Soils. 1993;16(3):227-232.

21. Devliegher W, Verstraete W. Lumbricus terrestris in a soil core experiment: nutrient-enrichment processes (NEP) and gut-associated processes (GAP) and their effect on microbial biomass and microbial activity. Soil Biol Biochem. 1995;27(12):1573-1580.

22. Scheu S. Automated measurement of the respiratory response of soil micro-compartments: active microbial biomass in earthworm faeces. Soil Biol Biochem. 1992;24(11):1113-1118.

23. Khambata SR, Bhat JV. Studies on a new oxalate-decomposing bacterium Pseudomonas oxalaticus. J Bacteriol. 1953;66(5):505-507.

24. Contreras E. Studies on the intestinal actinomycete flora of Eisenia lucen (Annelida, Oligochaeta). Pedobiologia. 1980;20:411-416.

25. Jolly JM, Lappin-Scott HM, Anderson JM, et al. Scanning electron microscopy of the gut microflora of two earthworms: Lumbricus terrestris and Octolasion cyaneum. Microbial Ecol. 1993;26(3):235-245.

26. Citernesi U, Neglia R, Seritti A, et al. Nitrogen fixation in the gastro-enteric cavity of soil animals. Soil Biol Biochem. 1977;9:71-72.

27. Karsten GR, Drake HL. Denitrifying bacteria in the earthworm gastrointes tinal tract and in vivo emission of nitrous oxide (N2O) by earthworms. Appl Environ Microbiol. 1997;63:1878-1882.

28. Singleton DR, Hendrixb PF, Colemanb DC, et al. Identification of uncultured bacteria tightly associated with the intestine of the earthworm Lumbricus rubellus (Lumbricidae; Oligochaeta). Soil Biol Biochem. 2003;35(12):1547-1555.

29. Binet F, Fayolle L, Pussard M. Significance of earthworms in stimulating soil microbial activity. Biol Fertil Soils. 1998;27(1):79-84.

30. Vivas A, Moreno B, Garcia-Rodriguez S, et al. Assessing the impact of composting and vermicomposting on bacterial community size and structure, and functional diversity of an olive-mill waste. Bioresour Technol. 2009;100(3):1319-1326.

31. Suhane RK. Vermicompost. Pusa: Publication of Rajendra Agriculture University; 2007.

32. Parthasarathi K, Ranganathan LS. Pressmud vermicast are hot spots of fungi and bacteria. Ecol Environ Cons. 1998;4:81-86.

33. Haritha Devi S, Vijayalakshmi K, Pavana Jyotsna K, et al. Comparative assessment in enzyme activities and microbial populations during normal and vermicomposting. J Environ Biol. 2009;30(6):1013-1017.
34. Tiwari SC, Tiwari BK, Mishra RR. Microbial populations, enzyme activities and nitrogen, phosphorous, potassium enrichment in earthworm casts and in the surrounding soil of pine apple plantation. Biol Fertil Soils. $1989 ; 8(2): 178-182$

35. Toyota K, Kimura M. Microbial community indigenous to the earthworm Eisenia foetida. Biol Fertil Soils. 2000;31(3-4):187-190.

36. Devliegher W, Verstraete W. Microorganisms and soil physicochemical conditions in the drilosphere of Lumbricus terrestris. Soil Biol Biochem. 1997;29(11-12):1721-1729.

37. Kristufek V, Ravasz K, Pizl V. Actinomycete communities in earthworm guts and surrounding soil. Pedobiologia. 1993;37:379-384.

38. Tiquia SM. Microbiological parameters as indicators of compost maturity. J Appl Microbiol. 2005;99(4):816-828.

39. Sharpley AN, Syers JK. Potential role of earthworm casts for the phosphorous enrichment of runoff waters. Soil Biol Biochem. 1976;8(5):341-346.

40. Trevors JT. Dehydrogenase activity in soil. A comparison between the INT and TTC assay. Soil Biol Biochem. 1984;16:673-674.

41. Garcia C, Hernandez T, Costa F. Potential use of dehydrogenase activity as an index of microbial activity in degraded soils. Commun Soil Sci Plant Anal. 1997;28(1-2):123-134.

42. Vaz-Moreira I, Maria E, Silva CM, et al. Diversity of bacterial isolates from commercial and homemade composts. Microbial Ecol. 2008;55(4):714 722.

43. Pinel N, Davidson SK, Stahl DA. Verminephrobacter eiseniae gen. nov., sp. nov., a nephridial symbiont of the earthworm Eisenia foetida (Savigny). Int J Syst Evol Microbiol. 2008;58(Pt 9):2147-2157.

44. Zhang BG, Li GT, Shen TS, et al. Changes in microbial biomass C, N, and $\mathrm{P}$ and enzyme activities in soil incubated with the earthworms Metaphire guillelmi or Eisenia foetida. Soil Biol Biochem. 2000;32(14):2055-2062.

45. Aira M, Monroy F, Dominguez J. Earthworms strongly modify microbial biomass and activity triggering enzymatic activities during vermicomposting independently of the application rates of pig slurry. Sci Total Environ. 2007;385(1-3):252-261.

46. Nechitaylo TY, Yakimov MM, Godinho M, et al. Effect of the earthworms Lumbricus terrestris and Aporrectodea caliginosa on bacterial diversity in soil. Microbial Ecol. 2010;59(3):574-587.

47. Bohlen PJ, Edwards CA. Earthworm effects on N dynamics and soil respiration in microcosms receiving organic and inorganic nutrients. Soil Biol Biochem. 1995;27(3):341-348.

48. Lee YS, Bartlett RJ. Stimulation of plant growth by humic substances. Soil Sci Soc Am J. 1976;40(6):876-879.

49. Pathma J, Rahul GR, Kamaraj Kennedy R, Subashri R, Sakthivel N. Secondary metabolite production by bacterial antagonists. Journal of Biological Control. 2011;25(3):165-181. 